entirely reconciled since the great Seminole wars at the beginning of the nineteenth century. Miss Densmore visited these Indians on behalf of the Smithsonian Institution, Washington, D.C., with the view of the investigation of their music, and although she had been assured that the Seminoles had no songs, she was successful, in the end, in obtaining two hundred phonograph records. In a preliminary statement issued by the Smithsonian Institution, Miss Densmore says that the Seminoles are ruled by 'old men', who remain in seclusion in the Everglades and are rarely seen. A rule is imposed upon the people that they are not to learn, or at least to speak, English. Intercourse with the whites is conducted by signs, except that sometimes they will name prices for the articles they wish to sell. They pride themselves on being a full-blood tribe, and a recent count gave 17 mixed bloods only in a population of 500 .

\section{Breeding Insects}

IN a useful note in the Vasculum for May (p. 61), Prof. J. W. Heslop Harrison gives simple instructions for the breeding of insects for experimental and other purposes. This information about the materials used, the methods of constructing cages for moths and butterflies, and the rather unorthodox methods of wintering pupæ, should help to solve problems which have baffled willing but inexpert experimenters.

\section{Announcements}

Prof. C. G. Seligman, professor of ethnology in the University of London, has been awarded the Nelson Annandale Gold Medal of the Asiatic Society of Bengal for his "contributions to the study of Anthropology in Asia ". This medal, which is awarded triennially, was founded in 1927, and the only previous recipient was Dr. Fritz Sarasin, of the Museum für Völkerkunde, Basle.

The KING, on the recommendation of the Minister of Health, has approved the appointment of Miss Ruth Darwin as a senior commissioner of the Board of Control. Miss Darwin, who is a daughter of the late Sir Horace Darwin, was an honorary commissioner in 1920-30 and has been a commissioner since Jan. 1, 1931. She is a member of the committee recently appointed to consider certain issues arising in connexion with the sterilisation of the mentally unfit.

The twenty-fifth Conference of the Society for Experimental Biology will be held at the laboratory of the Marine Biological Association, Citadel Hill, Plymouth, on July 9-11. Some thirty papers are to be read, and on July 10 a visit will be paid to the laboratories and farms at Dartington Hall, Totnes.

THE fifty-first annual meeting of the Society of Chemical Industry will be held at Nottingham on July 12-15. The presidential address will be delivered on July 13 by Prof. G. T. Morgan, on "Ourselves and Kindred Societies ". On the following day, the Messel Medal will be presented to Sir William Pope, who will give an address on "Forty Years of Stereochemistry". The greater part of the meeting will be devoted to visits to works in the neighbourhood.

Applications are invited for the following appointments, on or before the dates mentioned:- An assistant lecturer in philosophy in the University of Manchester-The Registrar, University of Manchester (June 27). A reader in electrical engineering (telegraphy and telephony) at the Imperial College, City and Guilds College-The Academic Registrar, University of London, South Kensington, S.W.7 (July 1). An assistant in the Department of Agricultural Botany of the Edinburgh and East of Scotland College of Agriculture-The Secretary, Edinburgh and East of Scotland College of Agriculture, 13 George Square, Edinburgh (July 1). A full-time master for zoology and botany at the Medway Technical College, GillinghamHead of the Senior Departments, Medway Technical College, Gillingham, Kent (July I). An assistant lecturer in pharmaceutics at the Cardiff Technical College-The Director of Education, City Hall, Cardiff (July 2). An assistant lecturer in geology in the University of Manchester-The Registrar, University, Manchester (July 2). A William Morris Research Fellow in Radiology at Mount Vernon Hospital-The Secretary of the British Empire Cancer Campaign, 12 Grosvenor Crescent, S.W.1 (July 2). A part-time lecturer in the Biology Department of the Plymouth and Devonport Technical College-The Secretary for Education, Education Office, Rowe Street, Plymouth (July 5). An Alfred Fripp Memorial Fellow in Child Psychology at Guy's Hospital-The Dean, Guy's Hospital Medical School, S.E.I (July 8). A professor of electrical engineering at the Manchester Municipal College of Technology-The Registrar, College of Technology, Manchester (July 9). A lecturer in physics and mathematics at the Sir John Cass Technical Institute-The Principal, Sir John Cass Technical Institute, Jewry Street, E.C.3 (July 9). A head of the Chemistry Department of the Sunderland Technical College-The Principal, Technical College, Sunderland (July 11). A lecturer in zoology at the Victoria University College, Wellington, New Zealand - The Secretary, Universities Bureau of the British Empire, 88A Gower Street, W.C.I (July 12). Chemists in the Department of the Government ChemistThe Government Chemist, Clement's Inn Passage, W.C.2 (July 16). A senior lecturer in economics and politics at the Rhodes University College, Grahamstown-The Secretary, Office of the High Commissioner for the Union of South Africa, 73 Strand, W.C.2 (July 30). Evening instructors in advanced building construction, sanitary engineering, and physics, at the Kingston-upon-Thames Technical College - The Principal, Technical College, Kingston-upon-Thames. An assistant master for mathematics at the Halifax Municipal Technical College--The Principal, Municipal Technical College, Halifax. A lecturer in physiology at the Chelsea Polytechnic-The Principal, Chelsea Polytechnic, Manresa Road, S.W.3. A wholetime lecturer in biology in the Department of Anatomy of the University of Durham College of Medicine-The Registrar, University of Durham College of Medicine, Newcastle-upon-Tyne.

No. 3269, VoL. 129] 